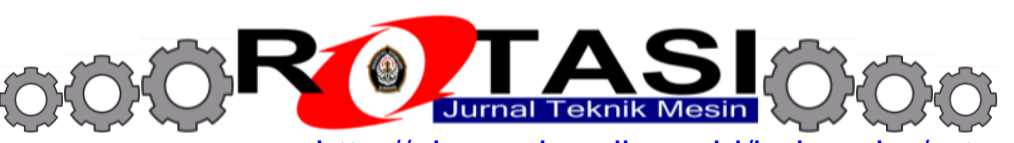

Available online at Website http://ejournal.undip.ac.id/index.php/rotasi

\title{
PENINGKATAN EFISIENSI KOMPOR GAS DENGAN PENGHEMAT BAHAN BAKAR ELEKTROLIZER
}

\author{
*Bambang Yunianto, Dwi Septiani \\ Jurusan Teknik Mesin, Fakultas Teknik, Universitas Diponegoro \\ Jl.Prof.Sudarto, Tembalang, Semarang, Indonesia \\ *E-mail: b_yunianto@undip.ac.id
}

\begin{abstract}
ABSTRAK
Beberapa metode penghemat bahan bakar pada kompor gas telah dibuat dan diuji cobakan salah satunya adalah penggunaan penghemat bahan bakar elektrolizer. Prinsip alat ini adalah proses elektrolisis dengan dua elektroda yang dimasukkan didalam larutan elektrolit (campuran air- $\mathrm{NaOH}$ ). Dengan dialiri arus listrik DC pada dua elektrode, akan timbul gas HHO (gas Brown) yang bersamasama dengan gas LPG dapat meningkatkan proses pembakaran dalam kompor gas. Dengan memvariasikan konsentrasi NAOH dalam larutan maka akan terjadi perubahan efisiensi pembakaran. Dalam pengujian dihasilkan bahwa pada kosentrasi NAOH $33 \%$ dan arus DC 1.7 Ampere, diperoleh peningkatan efisiensi pembakaran tertinggi, yaitu didapat penghematan gas LPG hingga $19 \%$.
\end{abstract}

Kata kunci: efisiensi, elektrolisis, gas brown, kompor gas

\section{PENDAHULUAN}

Konversi energi dari minyak ke Gas LPG memberikan dampak peningkatan konsumsi LPG di Indonesia. kususnya di kalangan industri kecil dan rumah tangga perkotaan. Hal ini memicu kelangkaan pasokan LPG di pasaran, yang kemudian diikuti dengan kenaikan harga. Mengurangi masalah diatas beberapa alternatif perlu dibuat antara lain penggunaan kembali tungku kayu bakar yang efisien [1], pembuatan kompor minyak yang hemat bahan bakar dengan tambahan alat berupa tangki minyak bertekanan [2], pengaturan metoda penyalaan kompor minyak dengan mengatur jumlah sumbu kompor, mengatur tinggi rendahnya sumbu kompor terhadap panci [3].

Secara kusus terhadap pemanfaatan LPG, dilakukan pencarian metoda penghematan konsumsi bahan bakar LPG dalam kompor Gas. Metoda terakhir ini yang kami lakukan, yaitu dengan membuat dan menguji penggunakan alat penghemat bahan bakar LPG. Alat ini berupa reaktor (elektrolizer) yang memproduksi gas HHO (gas Brown) yang pada proses berikutnya menjadi komponen hidrogen yang merupakan bahan bakar dengan nilai kalor yang tinggi. Komponen alat ini berupa katoda -anoda dalam tabung plastik yang berisi elektrolit air - NaOH. Elektorlit ini dialiri listrik arus searah dari Accu yang akan menghasilkan gas-HHO dan bersama-sama gas LPG masuk kedalam saluran kompor gas. Gas LPG bersama-sama gas HHO akan meningkatkan efisiensi pembakaran , sehingga komsumsi LPG kompor gas akan berkurang.

Besar-kecilnya penghematan LPG dalam Kompor gas dipengaruhi oleh beberapa hal antara lain, perbandingan camputan larutan $\mathrm{NaOH}$ terhadap air, jenis dan bahan lempeng Katoda dan Anoda serta besar kecilnya arus listrik yang mengalir..Dalam penelitian ini kami lakukan beberapa pengujian, yaitu:

1) Mengetahui peningkatan efisiensi Kompor Gas dengan dilengkapinya alat bantu penghemat bahan bakar LPG.

2) Mendapatkan arus terbaik yang dialirkan dalam alat bantu penghemat LPG.

3) Menghasilkan satu peralatan bantu penghemat LPG yang sederhana dan murah dibuat.

\section{STUDI PUSTAKA}

\subsection{Penghemat Bahan Bakar Elektrolizer HHO}

Alat penghemat bahan bakar Elektrolizer pada prinsipnya adalah proses elektrolisa, yang merupakan proses kimia yang menguraikan ikatan molekul air menjadi gas hidrogen dan oksigen dengan bantuan arus listrik. Pada proses elektrolisis terdapat katoda (kutub negatif) dan anoda (kutub positip) yang berada dalam larutan elektroda $\mathrm{NaOH}$. Larutan ini bersama katoda dan anoda yang dialiri arus listrik searah dari Battery akan menghasilkan gas HHO (gas Brown). HHO merupakan gas yang labil sebelum menjadi hidrogen. Proses elektrolisa ini digambarkan pada Gambar 1.

Elektrolit $\mathrm{NaOH}$ merupakan salah satu jenis elektrolit yang berfungsi sebagai katalisator untuk terurainya air menjadi ion hidrogen dan oksigen yang berasal dari air. Jumlah atau konsentrasi elektrolit dalam air , sangat berpengaruh terhadap terbentuknya gas HHO. 


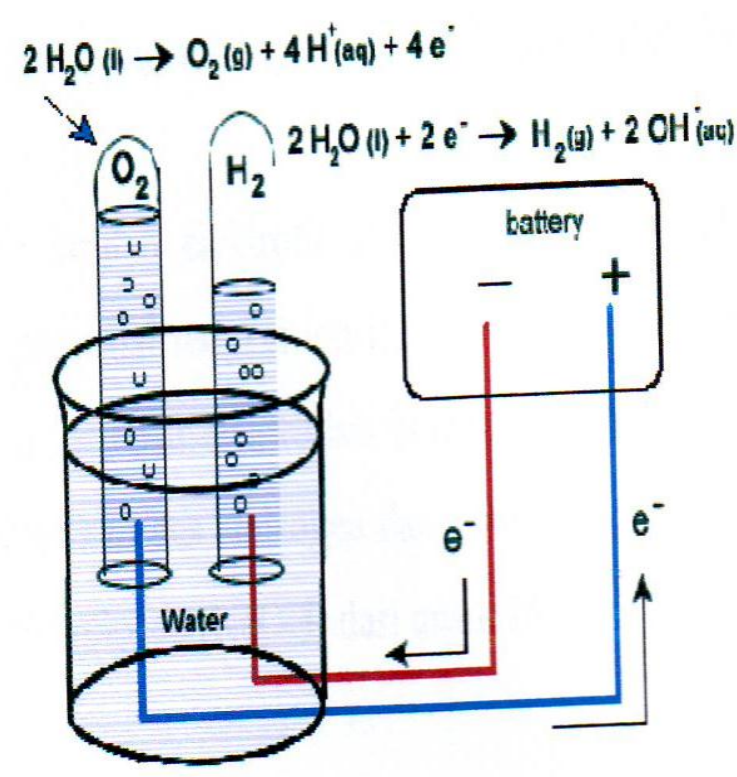

Gambar 1. Skema proses elektrolisa

\subsection{Proses Elektrolisis}

Dalam proses elektrolisis, ketika terjadi penguraian air $(\mathrm{H} 2 \mathrm{O})$ menjadi hidrogen $(\mathrm{H} 2)$ dan Oksigen $(\mathrm{O} 2)$, dua molekul air menangkap dua elektron dari katode sehingga menjadi gas $\mathrm{H} 2$ dan ion hidroksida $(\mathrm{OH})$. Sementara pada kutub Anode, dua molekul air lainnya akan terurai menjadi gas Oksigen dengan 4 ion $\mathrm{H}^{+}$dan $\mathrm{OH}^{-}$yang selanjutnya akan mengalami proses netral ke molekul air kembali.. Gas oksigen dan gelembung gas hidrogen terlepas dari permukaan elektrolit, partikel tersebut akan berikatan kembali menjadi gas Brown (HHO)

Reaksi elektrolisis larutan $\mathrm{NaOH}$ dalam air dinyatakan dengan reaksi berikut [4].

Katoda:

$\left(2 \mathrm{H}_{2} \mathrm{O}+2 \mathrm{e} \ldots . . . .>2 \mathrm{OH}+\mathrm{H}_{2}\right) \times 2$

Anoda:

$4 \mathrm{OH}$

$$
2 \mathrm{H}_{2} \mathrm{O}+\mathrm{O}_{2}+4 \mathrm{e}
$$

$2 \mathrm{H} 2 \mathrm{O}$ $2 \mathrm{H} 2+\mathrm{O} 2$

Komponen penting dalam proses elektrolisis adalah tabung elektrolisis yang didalamnya terdapat elektrode, yang terdiri dari katode dan anode. Pada elektrode inilah arus listrik searah dialirkan dalam larutan elektrolit.

Dengan alat ini arus listrik akan mengubah struktur atom hydrogen (H2) dan Oksigen (O2) pada air dari bentuk diatomik menjadi monotomik. Ikatan neutron yang mengikat $\mathrm{H}$ dan $\mathrm{O}$ akan terlepas, sehingga $\mathrm{H}$ akan tertarik ke kutub positip dan $\mathrm{O}$ akan tertarik ke kutub negatip. Sejalan dengan proses tersebut, gelembung $\mathrm{H}$ dan $\mathrm{O}$ akan bertambah menempel pada elektrode, kemudian terlepas naik kepermukaan larutan elektrolit. Saat gelembung gas hidrogen dan oksigen monotomik terlepas dari permukaan, gas-gas tersebut akan berikatan kembali menjadi gas brown atau HHO [5].

Tabung elektrolis yang digunakan dalam pengujian dapat dibuat dari bahan sederhana seperti tabung plastik, atau tabung -tabung berbahan sederhana lainnya, karena pada tabung ini tidak menerima tekanan tinggi. Sedangkan bahan elektrode yang digunakan adalah baja tahan karat (stainless steel) yang mempunyai sifat tahan korosi terhadap larutan elektrolit. Pada bagian elektroda, bahan anoda lebih tahan terhadap korosi sementara katoda lebih mudah berkarat/korosi. Ukuran dan tipe elektrode disesuaikan dengan ukuran tabung. Tipe elektroda ada beberapa bentuk, yaitu yang paling umum berbentuk plat atau silinder.

Elektrolit merupakan cairan yang berfungsi sebagai katalis artinya berfungsi sebagai bahan perantara untuk mempercepat proses reaksi tanpa terjadi perubahan sifat kimianya. Elektrolit merupakan larutan yang terdiri air (aquades) dan katalisator pada prosentase tertentu. Jenis -jenis katalisator antara lain, $\mathrm{NaOH}, \mathrm{KOH}$ ataupun $\mathrm{H} 2 \mathrm{SO} 4$ [6]. 


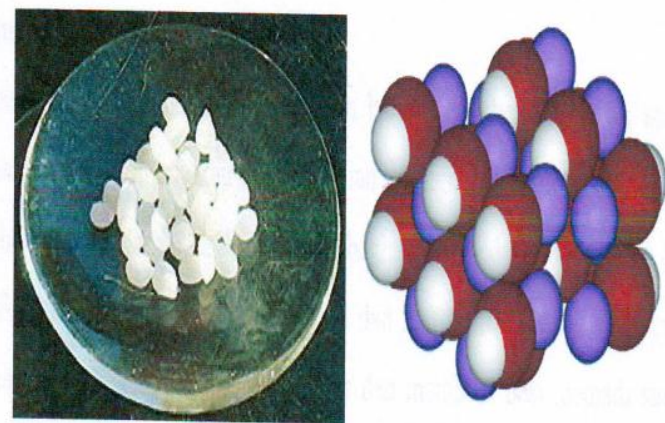

Gambar 2. Butiran $\mathrm{NaOH}$

Karakteristik masing-masing katalisator berbeda beda dan mempunyai kelebihan dan kelemahan masingmasing. Pada pengujian ini digunakan katalis $\mathrm{NaOH}$, yang juga dikenal sebagai soda api atau sodium hidroksida, seperti ditunjukkan dalam Gambar 2. Natrium hoidroksida $(\mathrm{NaOH})$ terbentuk dari oksida basa (Natrium Oksida) yang dilarutkan dalam air. Katalis ini bersifat basa dan banyak digunakan dalam proses industri, seperti kertas, sabun dan diterjen. Bentuk fisik $\mathrm{NaOH}$ murni adalah dalam bentuk putih padat yang tersedia dalam bentuk pelet, butiran ataupun larutan jenuh. Bahan ini bersifat lembab cair dan mudah menyerap karbon dioksida dari udara bebas. Sifat lain juga mudah larut dalam air, walaupun tidak selarut $\mathrm{KOH}$, katalis ini akan melepaskan panas ketika dilarutkan.

\section{METODOLOGI PENELITIAN}

\subsection{Instalasi alat uji penghemat bahan bakar elektrolizer}

Pemasangan alat penghemat bahan bakar elektrolizer ditunjukkan dalam Gambar 3 dengan diskripsi komponenkomponen sebagai berikut:

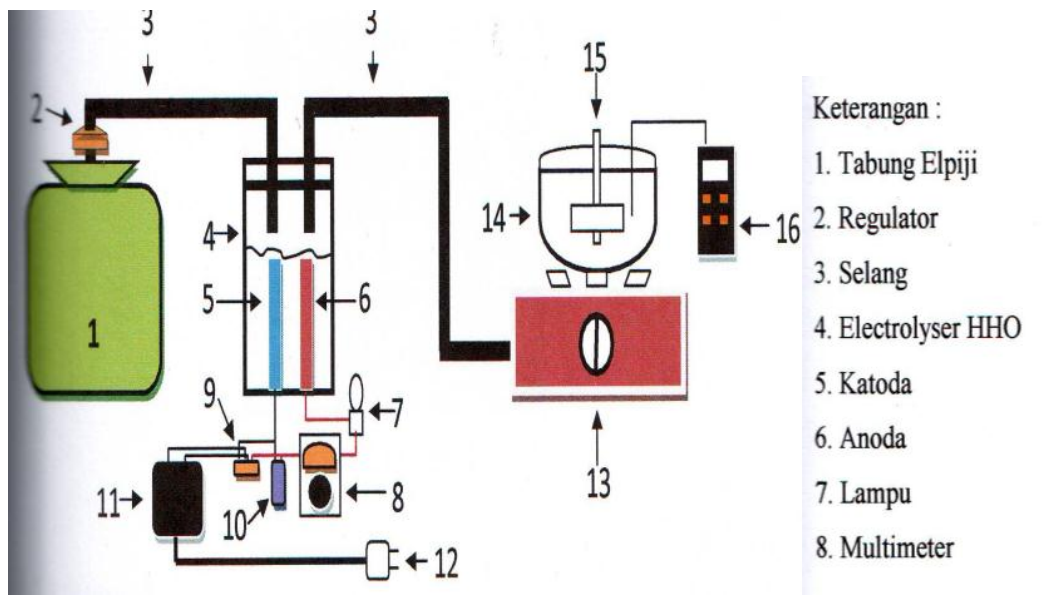

Gambar 3. Instalasi alat penghemat Elektrolizer

Adapun alat Elektrolizer dibuat dari beberapa komponen, yaitu tabung elektrolisis dan elektroda (katoda dan anoda). Tabung elktrolisis dibuat dari tabung galvanis dengan diameter $8 \mathrm{~cm}$ dan tinggi $30 \mathrm{~cm}$. Sedangkan elektroda dibuat dari 4 lempeng baja tahan karat dengan ukuran panjang, lebar dan tebal berturut-turut $10 \mathrm{~cm}, 4 \mathrm{~cm} \mathrm{dan} 1 \mathrm{~mm}$. Dua lempeng berfungsi sebagai katode dan dua lempeng lainnya sebagai anoda. Pada masing-masing ujung katoda atau anoda dipasang kabel listrik untuk mengalirkan arus listrik DC dari penyearah.

\subsection{Prosedur pengujian}

Setelah tes awal dilakukan dan diketahui alat dapat bekerja dengan baik maka dimulailah pengujian untuk mendapatkan data. Pengujian dilaksanakan dengan dua tahap, yaitu pengujian tanpa alat penghemat (tahap 1) dan dengan alat penghemat (tahap2). Data pengujian yang diambil adalah sama yaitu jumlah (berat) gas yang dipakai selama kurun waktu tertentu atau selama proses pemanasan air hingga temperatur $90 \mathrm{C}$. Untuk pengujian yang menggunakan alat penghemat elektrolizer, diukur pula besar arus pada setiap pergantian konsentrasi laruran $\mathrm{NaOH}$. Prestasi alat penghemat bahan bakar elektrolizer diketahui dari prosentasi penghematan bahan bakar LPG yang dikonsumsi, yang dinyatakan dengan persamaan berikut.

Prosentasi penghematan $(\mathrm{PH})=$, 


\section{$m 1-m 2=x 100 \%$ $m 1$}

dimana:

$\mathrm{m} 1$ = masa LPG tanpa alat penghemat

$\mathrm{m} 2$ = masa LPG denganalat penghemat

\section{HASIL PENGUJIAN DAN BAHASAN}

Hasil pengujian disajikan dalam dua data utama yaitu:

1) Data hasil pengujian kompor gas dengan bahan bakar $100 \%$ LPG tanpa alat penghemat elektrolizer (LPG murni).

2) Data hasil pengujian kompor gas LPG dengan alat penghemat elektrolizer (LPG + elektolit $\mathrm{NaOH}$ ).

Elektrolit yang digunakan dalam alat penghemat ini terdiri dari campuran aquades dan larutan $\mathrm{NaOH}$ yang terdiri dari 5 variasi dengan perbandingan aquades terhadap $\mathrm{NaOH}$ sebagai berikut;

- Konsentrasi 1,5 liter aquades : 1 gram $\mathrm{NaOH}(=7 \%)$

- Konsentrasi 1,5 liter aquades : 2 gram $\mathrm{NaOH}(=13 \%)$

- Konsentrasi 1,5 liter aquades : 3 gram $\mathrm{NaOH}(=20 \%)$

- Konsentrasi 1,5 liter aquades : 4 gram $\mathrm{NaOH}(=27 \%)$

- Konsentrasi 1,5 liter aquades : 5 gram $\mathrm{NaOH}(=33 \%)$

- Konsentrasi 1,5 liter aquades : 6 gram $\mathrm{NaOH}(=40 \%)$

Hasil dari data pengujian dan perhitungan prosentasi penghematan LPG disajikan dalam grafik berikut:

\subsection{Pengaruh konsentrasi larutan elektrolit terhadap penghematan LPG}

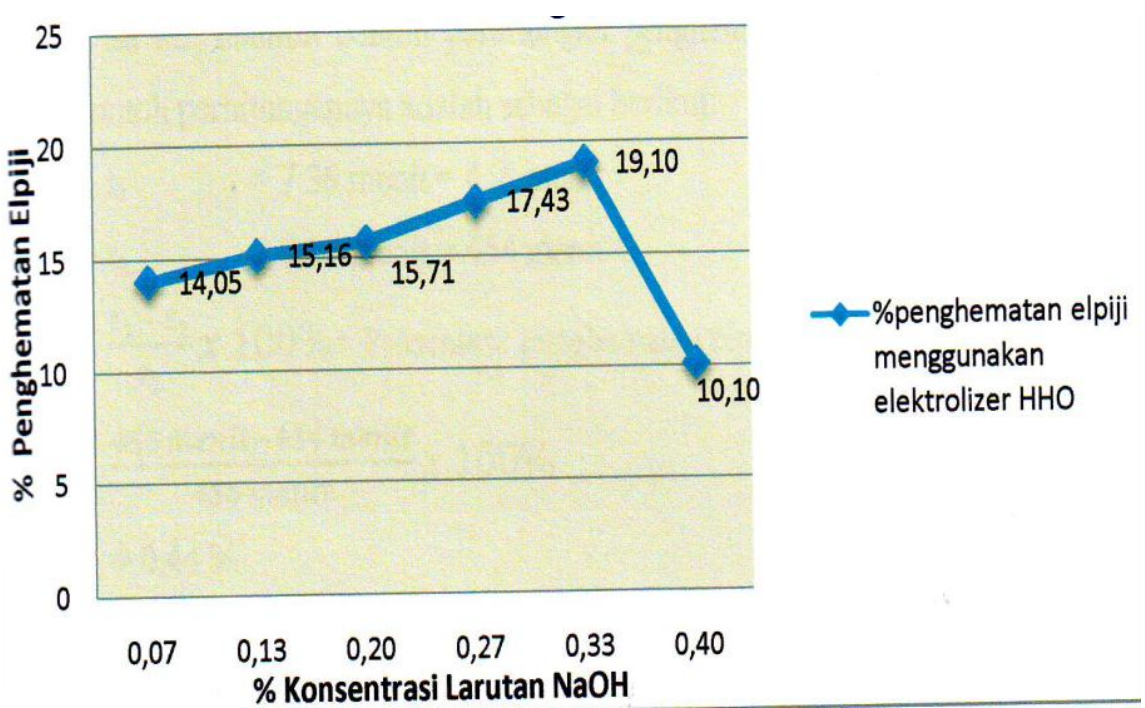

Gambar 4. Hubungan prosentase penghematan dengan kosentrasi larutan

Dari Grafik 4 ditunjukkan bahwa penggunaan alat penghemat elektrolizer mampu meningkatkan penghematan LPG pada penggunaan kompor gas . Pada konsentrasi larutan elektrolit 7\% diperoleh peningkatan penghematan LPG $14 \%$. Penghematan akan meningkat sejalan dengan meningkatnya konsentrasi larutan. Penghematan maximum terjadi pada kesentrasi larutan elektrolit $33 \%$. Namun dengan ditambahnya larutan $\mathrm{NaOH}$ hingga kosentrasi $40 \%$, justru terjadi penurunan penghematan yaitu turun menjadi $10 \%$, seperti ditunjukkan dalam Gambar 4. Terjadinya peningkatan penghematan LPG pada kompor gas dengan alat elektrolizer, menunjukkan bahwa, pada proses elektrolisis dalam alat elektrolizer terjadi pembentukan gas Brown (HHO) yang masuk kedalam kompor gas. Gas HHO ini ikut terbakar sehingga mengurangi konsumsi gas LPG yang masuk ke proses pembakaran. Pembentukan gas HHO dipengaruhi tingkat konsentrsasi larutannya.

Dengan meningkatnya konsentrasi larutan akan meningkatkan terbentuknya gas HHO. Peningkatan terbentuknya gas HHO disebabkan terjadinya peningkatan arus listrik yang terjadi pada dua elektroda dalam larutan elektrolit, yang besarnya dipengaruhi oleh tegangan input dan konsentrasi larutan. Juga dapat dijelaskan peningatan gas HHO akan menurun setelah larutan pada kosentrasi $40 \%$. Hal ini disebabkan karena dengan pekatnya larutan elektrolit, maka perlu dibutuhkan voltase input yang lebih besar. Pada pengujian ini, voltase input diatur tetap (12 volt), sehingga tidak mampu untuk meningkatkan arus listrik dalam larutan yang pada gilirannya tidak mampu meningkatkan produksi gas HHO. Jadi untuk meningkatkan produksi gas HHO pada kosentrasi yang tinggi, maka arus listrik yang dihasilkan harus 
ditingkatkan yaitu dengan menaikkan voltase. Jika hal ini dilakukan akan mempunyai dampak lain yaitu alat menjadi berat dan mahal karena membutuhkan perubahan peralatan pada penyedia dayanya, sehingga tujuan penggunaan alat penghemat LPG yang sederhana dan murah menjadi tidak tercapai.

\subsection{Pengaruh konsentrasi larutan elektrolit terhadap waktu pemanasan air}

Pemasangan alat penghemat elektrolizer jika dibandingkan dengan penggunaan kompor gas dengan bahan bakar $100 \%$ LPG, menunjukkan terjadinya penghematan LPG yang digunakan. Penghematan energi LPG ini erat hubungannya dengan waktu pemanasan air yang dibutuhkan. Pada pemanasan air hingga suhu tertentu maka dengan meningkatnya penghematan LPG maka terjadi pula penghematan waktu pemanasan yang diperlukan. Penjelasan dapat ditunjukkan dengan Gambar 5.

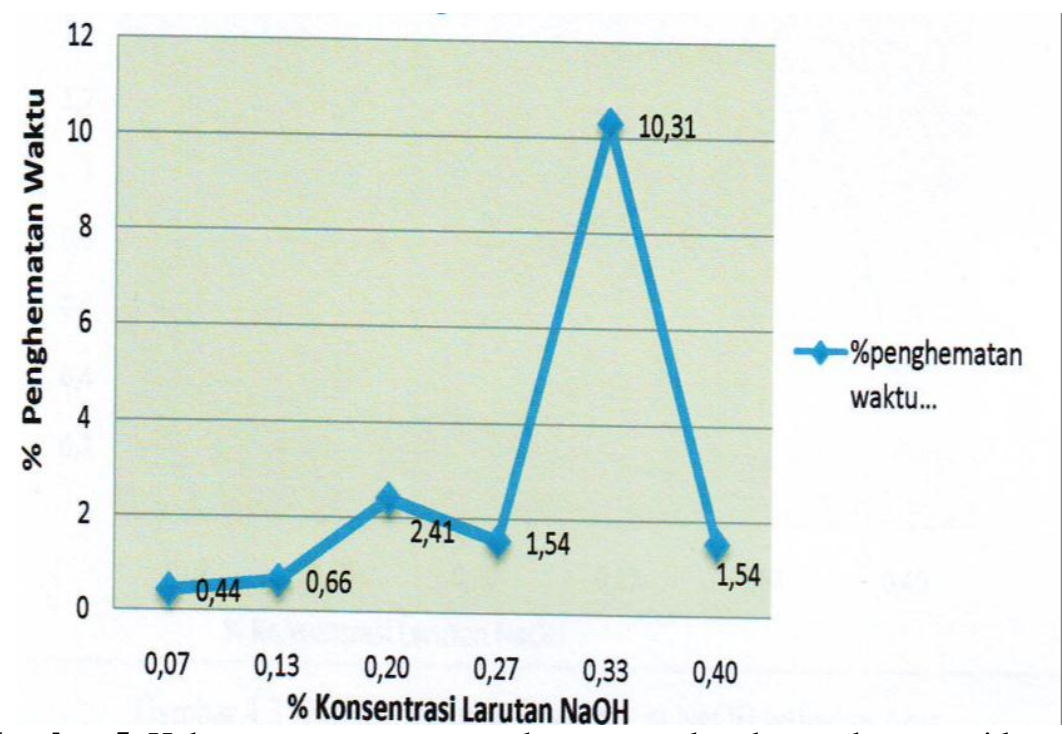

Gambar 5. Hubungan prosentase penghematan waktu dengan kosentrasi larutan

Pada peningkatan kosentrasi larutan, dapat ditunjukkan penghematan waktu yang dibutuhkan. Serupa dengan penghematan LPG, maka makin tinggi konsentrasi terjadi pula peningkatan penghematan waktu yang diperlukan untuk pemanasan air. Penghematan waktu maksimum $(10 \%)$ terjadi juga pada kosentrasi larutan $33 \%$. Peningkatan konsentrasi selanjutnya justru akan menurunkan penghematan waktu pemanasan. Jadi pada kosentrasi larutan $33 \%$, disamping terjadi pengh Pada peningkatan kosentrasi larutan, dapat ditunjukkan penghematan waktu yang dibutuhkan. Serupa dengan penghematan LPG, maka makin tinggi konsentrasi terjadi pula peningkatan penghematan waktu yang diperlukan untuk pemanasan air. Penghematan waktu maksimum (10\%) terjadi juga pada kosentrasi larutan $33 \%$. Peningkatan konsentrasi selanjutnya justru akan menurunkan penghematan waktu pemanasan. Jadi pada kosentrasi larutan $33 \%$, disamping terjadi penghematan bahan bakar LPG ,juga terjadi waktu yang paling singkat (penghematan waktu maksimum) untuk memanaskan air.ematan bahan bakar LPG ,juga terjadi waktu yang paling singkat (penghematan waktu maksimum) untuk memanaskan air.

\subsection{Pengaruh konsentrasi larutan elektrolit terhadap arus listrik}

Alat penghemat elektrolizer bekerja karena adanya 2 elektroda (katoda dan anoda) dalam larutan elektrolit yang bisa aktif menghasilkan ion-ion akibat adanya arus listrik dan tegangan listrik. Pada pengujian pada alat ini digunakan tegangan (voltase) listrik yang tetap yaitu 12 volt.

Arus listrik yang dihasilkan dipengaruhi oleh kosentrasi larutan. Dari Gambar 6 dapat ditunjukkan bahwa perubahan kosentrasi akan meningkatkan arus listrik yang dihasilkan. Arus listrik tertinggi akan tercapai pada kosentrasi $33 \%$ yaitu sebesar 1,7 ampere. Pada kosentrasi lebih tinggi lagi (40\%), akan terjadi penurunan arus listrik yang tajam yaitu hanya 0,4 ampere.

Hal ini menunjukkan bahwa larutan sudah mencapai titik jenuh untuk memproduksi ion-ion listrik, sehingga tidak mampu lagi menghasilkan kenaikan arus listrik pada larutan. Jika alat ini ingin ditingkatkan titik jenuh konsentrasi larutan, maka diperlukan tegangan yang lebih tinggi dari 12 volt, yang tentunya mempunyai konsekwensi seperti yang sudah dijelaskan di bahasan diatas 


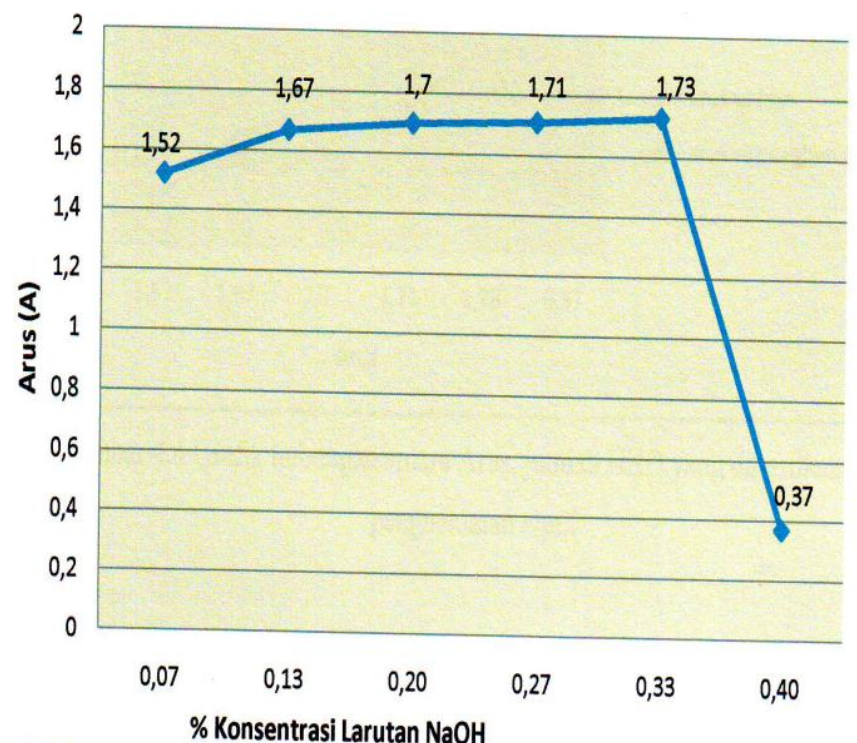

Gambar 6. Grafik Hubungan Konsentrasi $\mathrm{NaOH}$ terhadap Arus

\section{KESIMPULAN}

Dari hasil pengujian dengan digunakannya alat penghemat elektrolizer pada kompor gas LPG, dapat disimpulkan sebagai berikut:

1) Diperoleh penghematan bahan bakar LPG dibandingkan dengan penggunaan kompor gas tanpa alat penghemat yang besarnya bervariasi, dan penghematan tertinggi $19 \%$ yang terjadi pada kosentrasi larutan $33 \%$.

2) Penghematan waktu dan arus tertinggi yang dihasilkan juga terjadi pada kosentrasi $33 \%$, yang masing-masing besarnya $10 \%$ dan 1,7 ampere.

3) Alat penghemat elektrolizer yang kami uji dapat bekerja dengan efisien jika dioperasikan pada voltase input 12 volt, arus 1,7 ampere dan kosentrasi $33 \%$.

\section{DAFTAR PUSTAKA}

1. Bambang Yunianto, 2010, "Disain Tungku kayu bakar rendah polusi untuk industri kecil dan masarakat pedesaan,”. Teknik Mesin UNDIP, Semarang.

2. Fitriadi S, Nasarudin S, 2008, “Kaji eksperimen kompor tekan minyak tanah," Teknik Mesin UNDIP, Semarang.

3. Hayat P, Nasarudin S, 2006, "Kaji eksperimen kompor minyak tanah tipe sumbu tunggal dalam upaya peningkatan efisiensi konsumsi bahan bakar",Teknik Mesin Undip, Semarang.

4. Manubinuri, Sulis , 2010 ,"Pengujian Elektrolisis dengan variasi konsentrasi dan tegangan pada system Brown gas", Teknik Mesin ITS Surabaya.

5. Ariana, made, 2009, "Kaji eksperimen pengaruh penggunaan gas hasil elektrolisis terhadap unjuk kerja motor disel,". Teknik mesin ITS, Surabaya.

6. Hamidy, Habib, 2010, "Analisis pemanfaatan air sebagai energy alternatif pada produk kompor skala rumah tangga," Teknik mesin, ITS Surabaya. 